\title{
Report of 73 cases of cutaneous sporotrichosis in Mexico*
}

\author{
Roberto Estrada-Castañón¹, Guadalupe Chávez-López¹, Guadalupe Estrada-Chávez², \\ Alexandro Bonifaz ${ }^{3}$
}

DOI: http:/ / dx.doi.org/10.1590/abd1806-4841.20187726

\begin{abstract}
We report 73 cases of cutaneous sporotrichosis from the Community Dermatology program, at the central and mountain areas of the state of Guerrero, Mexico. A similar number of cases was found between children and adults, mostly peasants and school-age children with rural occupations. Upper limbs were the mostly affected and the predominant clinical form was lymphocutaneous (56.16\%). All cultures corresponded to Sporothrix schenckii (sl). Treatment was done with potassium iodide in 54 patients, achieving clinical and mycological cure in all cases.
\end{abstract}

Keywords: Community health services; Community medicine; Dermatology; Potassium iodide; Sporothrix; Sporotrichosis

The Community Dermatology program was initiated at the Guerrero State in Mexico (southwest from Mexico City), reporting its importance and some studies done previously. ${ }^{1,2}$ During the activities, 13 communities with high marginality index were visited, at the Central and Mountain areas of the State (regions: Ahuacatepec, Colotepec, El Durazno, Hueycantenango and Acatepec). All of them are located between 1600-1900 m.a.s.l, with rain flow of 1600-2400 $\mathrm{mm}^{3}$ /year and tropical and subtropical climate, with temperature ranging from $12-32^{\circ} \mathrm{C}$ and vegetation includes tropical rainforest and coniferous forests. Local level schooling is 4th grade of elementary school and illiteracy ranges from 18\%-35\%. One thousand six hundred and fifty-four consultations were provided, from which
73 cases of sporotrichosis were confirmed (Figure 1). The general data are described in table 1. Full medical chart as well as mycological studies were made to all patients with clinical diagnosis of sporotrichosis, including culture in Sabouraud dextrose agar with and without antibiotics, and identification according to macromorphological characteristics, as well as reproductive forms. In some cases, a biopsy was taken and processed with H\&E, PAS and Grocott. Intradermal reaction with sporotrichin was performed in some patients with a 48-hour delayed reading. All patients were treated with potassium iodide; children 1-3 g/daily and adults 3-6 g/daily for 2 months; in patients with active lesions the treatment was extended for another month. Both treatment schemes were initiated in

Received 07 October 2017

Accepted 31 March 2018.

* Work conducted at the Hospital General de Acapulco Guerrero S.S, Acapulco Guerrero, Mexico.

Financial support: The Community Dermatology project has received support from the Secretaria de Salud del Estado de Guerrero and DIF (estatal), as well as the Fundación Mexicana para la Dermatología and Academia Mexicana de Dermatología.

Conflict of interest: None.

Service of Dermatology and Mycology, Hospital General de Acapulco S.S., Acapulco (Guerero), Mexico. Academical Unit of Medicine, Universidad Autónoma de Guerrero, Chilpancingo (Guerrero), Mexico.

Service of Dermatology and Department of Mycology, Hospital General de México "Dr. Eduardo Liceaga", Ciudad de México, Mexico.

MAILING AdDRESS:

Alexandro Bonifaz

E-mail: a_bonifaz@yahoo.com.mx

C2018 by Anais Brasileiros de Dermatologia 
low doses with gradual increase until higher doses were achieved. Sporotrichosis is a subcutaneous or implantation mycosis caused by Sporothrix schenckii complex; it includes several thermally di-

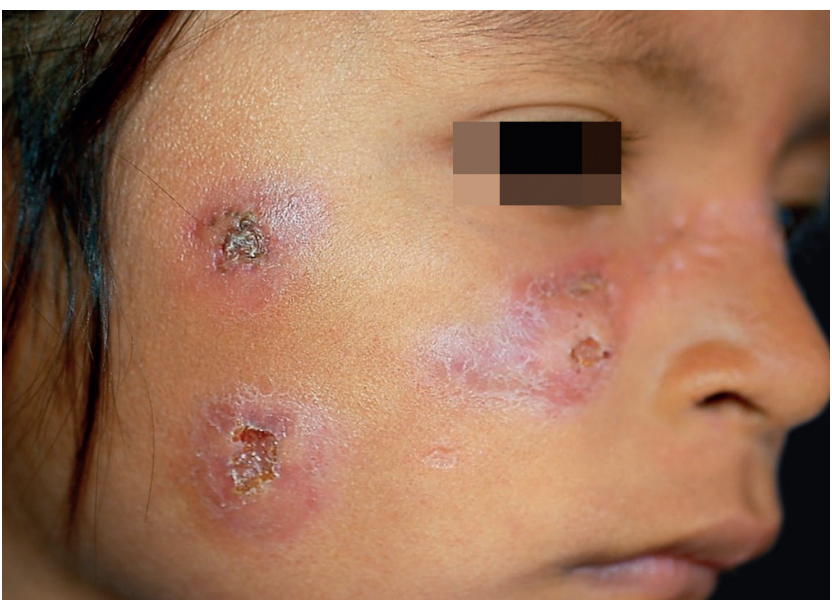

FigURE 1: Lymphocutaneous sporotrichosis in a child morphic fungal species, among which three are the most frequent in humans: Sporothrix schenckii (ss), Sporothrix brasiliensis and Sporothrix globosa. ${ }^{3,4}$ It has a worldwide distribution, being more frequent in tropical and subtropical areas. ${ }^{5}$ In Latin America there are three high endemic large areas. The first and most important one is localized at the south of Brazil, with S. brasiliensis, which caused a cat and dog outbreak and is considered a zoonosis, having affected nearly 4,000 humans. ${ }^{6}$ The second zone is at the Mountain region in the central-south region of Peru (Abancay), where up to 1,500 cases have been reported. ${ }^{78}$ The third area is in Mexico, with up to 1,000 reported cases. ${ }^{4}$ Most cases from Peru and Mexico are caused by S. schenckii. Guerrero State in Mexico at the Central and Mountain region is a high endemicity area with fewer cases but needed to be mentioned, is the low population index at these isolated communities. ${ }^{4,7}$ Orography, humidity and temperature are a suitable environment for the development of sporotrichosis. Fifty percent of the cases reported in this study were in children under 15 years of age or under, which implies that they are constantly in contact with the causative agent as they perform field activities, increasing the risk; consistent to other developing countries with similar statistics, both in population and traditions..$^{3-5,8}$ Most of previous studies re-

\begin{tabular}{|c|c|}
\hline Parameters & Results \\
\hline Dermatological consults & 1,654 \\
\hline Cases of sporotrichosis & 73 cases $(4.4 \%)$ \\
\hline \multirow[t]{4}{*}{ Age } & Youngest: 1 year; oldest: 76 years. \\
\hline & Average: 25.8 years \\
\hline & Children (<15 years old): 37 (50.68\%) \\
\hline & Adults: $36(49.31 \%)$ \\
\hline \multirow[t]{2}{*}{ Gender } & Male: 33 (45.2\%). \\
\hline & Female: $40(54.8 \%)$ \\
\hline \multirow[t]{4}{*}{ Occupation } & Peasants: $22(30.13 \%)$ \\
\hline & Housework and peasants: 14 (19.17\%) \\
\hline & Children with rural work: 24 (32.87\%) \\
\hline & Children without rural work: $13(17.80 \%)$ \\
\hline \multirow[t]{5}{*}{ Anatomical site } & Upper limbs: $30(41.09 \%)$ \\
\hline & Lower limbs: 16 (21.91\%) \\
\hline & Face: $16(21.91 \%)$ \\
\hline & Trunk: $3(4.10 \%)$ \\
\hline & Several locations: 8 (10.95\%) \\
\hline \multirow[t]{3}{*}{ Clinical features } & Lymphocutaneous: 41 (56.16\%) \\
\hline & Fixed cutaneous: $24(32.87 \%)$ \\
\hline & Disseminated cutaneous: 8 (10.95\%) \\
\hline \multirow[t]{3}{*}{ Mycological data } & Isolation of Sporothrix schenckii (sl): 73 (100\%) \\
\hline & Biopsy was performed: 29 (39.7\%), with suppurative granuloma. $4 / 29(13.7 \%)$ had elongated yeasts \\
\hline & Sporotrichin (skin reaction) was applied in: $44(60.2 \%) 43 / 44$ were positive $(97.7 \%)$ and $1 / 73$ negative $(2.2 \%)$ \\
\hline \multirow[t]{2}{*}{ Treatment } & Potassium iodide: 54/54 (100\%) achieved clinical and mycological cure. \\
\hline & Remaining patients did not attend subsequent visits \\
\hline
\end{tabular}


port a slight predominance in male gender. In contrast, we report a higher number of female cases; probably as women are equally exposed as they perform indoors and field activities daily. ${ }^{2}$ The most commonly affected clinical site was the upper and lower limbs but approximately one fourth of the cases affected the face, since it is the predominant location in children. ${ }^{4}$ Lymphocutaneous sporotrichosis (LCS) and fixed cutaneous sporotrichosis (FCS) were the most frequently observed (89\%), accordingly to what has been previously reported in the literature. ${ }^{3,49}$ However, it calls our attention that fixed forms are usually very mild and in different locations and can mimic other skin diseases such as tuberculosis, bacterial infections or nontuberculous mycobacteria. ${ }^{4}$ Sporotrichin is an intradermal antigen (peptide-rhamnomannan), which is extremely useful as its positivity is very helpful (24-48 hours). This is especially true when working at community dermatology level, and in our experience, it provides a general view on positive reactors making us aware on the extent of exposed patients in specific communities. ${ }^{3,4,9}$ Most Mexican strains are S. schenckii (ss) in $98 \%$ and rarely S. globosa. ${ }^{4,5}$ All our cases were confirmed by culture and fungal isolation corresponding morphologically to S. schenckii (sl). Histopathology in most cases with
LCS and FCS is not as useful, as it generally shows suppurative granulomas and occasionally mixed granulomas but with a low incidence of yeasts (long or cigar shaped yeasts and asteroid bodies), most reports go from 5 to $30 \%$. In disseminated cutaneous sporotrichosis (DCS), it is frequent to observe yeasts clusters. Four out of $29(13.7 \%)$ cases in which biopsy was taken corresponded precisely to DCS. ${ }^{3,4} \mathrm{We}$ are aware that first line treatment includes itraconazole due to its efficacy and less side effects. ${ }^{3,4,10}$ However, potassium iodide is easier to transport to the communities, is low-cost and easy to prepare in locum. We have a wide experience in the usage of this medication and we consider it in our conditions as a first line option as it provides short-term clinical results (approximately 2 months) with minimal side effects, which are mostly gastric intolerance and taste disturbances. Fifty-four (74\%) of our patients were evaluated later, all of which had clinical and mycological cure; the others did not attend follow up as mostly are dispersed in deeper areas of the mountains to perform field work. We report this series of cases as an example of community dermatology search of patients which shows new areas of endemic diseases as sporotrichosis, which has particular characteristics. $\square$

\section{REFERENCES}

1. Hay RJ, Andersson N, Estrada R. Mexico: community dermatology in Guerrero. Lancet. 1991;337:906-7.

2. Estrada R, Chavez-Lopez G, Estrada-Chavez G, Paredes-Solis S. Specialized dermatological care for marginalized populations and education at the primary care level: is community dermatology a feasible proposal? Int J Dermatol. 2012;51:1345-50.

3. Barros MB, de Almeida Paes R, Schubach A0. Sporothrix schenckii and Sporotrichosis. Clin Microbiol Rev. 2011;24:633-54.

4. Bonifaz A, Vázquez-González D. Sporotrichosis: an update. G Ital Dermatol Venereol. 2010;145:659-73.

5. Chakrabarti A, Bonifaz A, Gutierrez-Galhardo MC, Mochizuki T, Li S. Global epidemiology of sporotrichosis. Med Mycol. 2015;53:3-14.

6. Pereira SA, Gremião ID, Kitada AA, Boechat JS, Viana PG, Schubach TM. The epidemiological scenario of feline sporotrichosis in Rio de Janeiro, State of Rio de Janeiro, Brazil. Rev Soc Bras Med Trop. 2014;47:392-3.

7. Pappas PG, Tellez I, Deep AE, Nolasco D, Holgado W, Bustamante B. Sporotrichosis in Peru: description of an area of hyperendemicity. Clin Infect Dis. 2000;30:65-70.

8. Ramírez Soto MC. Sporotrichosis: The story of an Endemic Region in Peru over 28 Years (1985 to 2012). PLoS One. 2015;10:e0127924.

9. Bonifaz A, Araiza J, Pérez-Mejía A, Ochoa LA, Toriello C. Prueba intradérmica con esporotricina en una comunidad de la Sierra Norte de Puebla. Dermatol Rev Mex. 2013;57:428-32.

10. Marques GF, Martins AL, Sousa JM, Brandão LS, Wachholz PA, Masuda PY Characterization of sporotrichosis cases treated in a dermatologic teaching unit in the state of São Paulo - Brazil, 2003 - 2013. An Bras Dermatol. 2015:90:273-5.

\footnotetext{
AUTHORS'CONTRIBUTIONS

Roberto Estrada-Castañón $\quad$ (iD) ORCID 0000-0001-8508-7720

Approval of the final version of the manuscript, Intellectual participation in propaedeutic and/or therapeutic conduct of the cases studied, Critical review of the manuscript Guadalupe Chávez-López $\quad$ (iD) ORCID 0000-0001-6964-9818

Concepção e planejamento do estudo, Effective participation in research orientation, Critical review of the manuscript

Guadalupe Estrada-Chávez $\quad$ (iD) ORCID 0000-0001-8053-2602

Elaboration and writing of the manuscript, Effective participation in research orientation

Alexandro Bonifaz $\quad$ (iD) ORCID 0000-0003-2045-3317

Approval of the final version of the manuscript, Conception and planning of the study, Intellectual participation in propaedeutic and/or therapeutic conduct of the cases studied
}

How to cite this article: Estrada-Castañón R, Chávez-López G, Estrada-Chávez G, Bonifaz A. Report of 73 cases of cutaneous sporotrichosis in Mexico. An Bras Dermatol. 2018;93(6):907-9. 